\title{
Role of Sulforaphane on Histone Deacetylase Activity in Solid Ehrlich Carcinoma
}

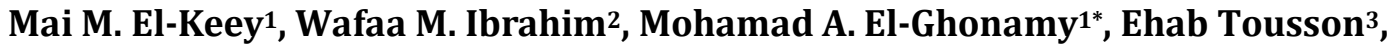 \\ Tarek M. Mohamed1 \\ ${ }^{1}$ Biochemistry Department, Faculty of Science, Tanta University, Tanta, Gharbiya \\ ${ }^{2}$ Medical Biochemistry Department, Faculty of Medicine, Tanta University, Tanta, Gharbiya \\ ${ }^{3}$ Zoology Department, Faculty of Science, Tanta University, Tanta, Gharbiya \\ Email: ${ }^{\star}$ mh_7akeem@hotmail.com
}

How to cite this paper: El-Keey, M.M., Ibrahim, W.M., El-Ghonamy, M.A., Tousson, E. and Mohamed, T.M. (2020) Role of Sulforaphane on Histone Deacetylase Activity in Solid Ehrlich Carcinoma. Journal of Biosciences and Medicines, 8, 104-118. https://doi.org/10.4236/jbm.2020.83010

Received: June 10, 2019

Accepted: March 6, 2020

Published: March 9, 2020

Copyright $(02020$ by author(s) and Scientific Research Publishing Inc. This work is licensed under the Creative Commons Attribution International License (CC BY 4.0).

http://creativecommons.org/licenses/by/4.0/

\begin{abstract}
Histone acylation is one in every of the posttranslational modification that incorporates a role within the regulation of sequence expression. This study was aimed to ameliorate neoplasm cell model Solid Ehrlich malignant neoplastic disease with sulforaphane extracted from cabbage alone and together with immune suppressant drug (MTX) by study the activity of simple protein deacetylase accelerator (HDAC). In this study, sulforaphane was extracted from cabbage leaves and evaluated victimization GC-MS and ultraviolet illumination spectrophotometry. 60 white male rats were divided into six equal groups. Group I: management ordinarily. The remaining mice were subjected to Ehrlich neoplasm cells. Group II: Tumor-bearing group. Group III: immune suppressant drug "MTX" treated group. Group IV, V treated with SFN before and when Paul Ehrlich cells implantation group VI (Methotrexate and sulforaphane-treated group). This result showed that sulforaphane was extracted from cabbage (Brassica oleracea) in concentration of 833 $\mu \mathrm{g} / \mathrm{g}$ leave. HDAC was attenuated when treatment with sulforaphane after treatment with methotrexate or sulforaphane alone. The desoxyribonucleic acid injury was attenuated in neoplasm tissue of tumor-bearing mice when treatment with immune suppressant drug and hyperbolic considerably in tumor tissue of tumor-bearing mice treated with sulforaphane before and after carcinogenesis and together with methotrexate treatment after carcinogenesis.
\end{abstract}

\section{Keywords}

Histone Deacetylase (HDAC), Sulforaphane (SFN), DNA Damage, Solid Ehrlich Carcinoma 


\section{Introduction}

Cancer is still the second leading explanation for death and is changing into the leading one in maturity in line with recent estimates [1] [2]. By 2030 cancer is predicted that because of the demographic changes alone, the number of recent cancer cases can increase by seventieth worldwide [3]. Experimental tumors have nice importance for the needs of modeling, and one among the most typical is that the bacteriologist pathology tumor, that springs from a spontaneous murine exocrine gland carcinoma [4]. Mutation studies have reported that chronic aerobic stress, especially from chronic inflammation, is related to carcinogenesis [5]. Additionally inducement polymer, macromolecule harm, and lipid, aerobic harm to macromolecule-coding or non-secret writing ribonucleic acid could probably cause errors within the synthesis of a protein or organic phenomenon dysregulation. This has been projected as Associate in nursing underlying mechanism of many human diseases [6]. Several living thing molecules, together with polymer, RNA, lipids, and proteins are generated, sterilization and damaging by aerobic stress once the pro-oxidant/anti-oxidant equilibrium is lost [7]. A standard adaptational response evoked in class a cell is that the up-regulation of stress-response genes upon the exposure to oxidants or aerobic stress-inducing agents, several of that cipher inhibitor defense enzymes. Induction of necrobiosis or mortification are made by high levels of ROS, increasing proof demonstrates that low or transient ROS exposure will increase cell proliferation, doubtless through altered expression of growth factors and proto-oncogenes [8].

Sirtuins and also the classical HDAC family are 2 supermolecule families with HDAC activity [9] [10]. Sirtuins are a category of proteins that possess simple protein deacetylase activity and are involved in transcriptional regulation, aging, stress resistance, apoptosis, energy potency, and application throughout low-calorie things. Sirtuins are NAD-dependent deacetylases whose protein activity is regulated by the magnitude relation of NAD+ to NADH. Category I and II are 2 completely different organic process categories that are the members of the classical HDAC family [11] [12].

HDACi operates by obstruction access to the situation (reversible or irreversible) of HDAC [13]. Though there are several inhibitors familiar, Trichostatin a (TSA) is that the most potent discovered to this point that may be a fermentation product of actinomycete, originally office was used as AN anti-fungal agent [14], it absolutely was discovered later that it's potent proliferation-inhibitory properties with cancer cells [15].

Glucosinolates (GSs) keep in plants are synthesized isothiocyanates (ITCs), by the chemical action breakdown of myrosinase and a thioglucoside glucohydrolase that principally they're gift within the crucifers and free throughout stress or harm and to some extent in the microflora of the enteral tract [16]; ITCs accumulates in the cells quickly, this accumulation levels could reach 100- to 200-fold over extracellular levels [16]. Sulforaphane (SFN) initial was isolated 
within the Nineteen Nineties from broccoli as associate degree inducer of part two enzymes (Xenobiotic metabolism), then varied studies have projected various antineoplastic pharmacologic aspects of SFN, thereby suggesting its potential as a promising candidate in cancer chemoprevention [17]. (SNF) is associate degree ITCs were isolated from broccoli within the early 1990s as an inducer of part two enzymes (Xenobiotic metabolism) and since then varied studies have projected various antineoplastic pharmacologic aspects of SFN, thereby suggesting its potential as a promising candidate within the chemoprevention of cancer [17]. Mechanisms of cancer chemoprevention by SFN are diversified and embody the alterations of matter metabolism through the induction of Nrf2-regulated genes of Phase-II detoxification enzymes (glutathione S-transferase, compound enzyme, glucuronosyltransferase, etc.) and therefore the inhibition of Phase-I enzymes that activate ototoxic chemical compounds, so lowering the amount of the carcinogens interacting with DNA. Additionally, there's a second necessary antitumor mechanism is the ability of SFN to dam cell proliferation and induce cell death of cancer cells, so reducing neoplasm growth [18]. Different studies rumored that cell death that is iatrogenic by SFN was related to p53 sequence activation [19].

This work was aimed to grasp the activity of simple protein deacetylase catalyst (HDAC) in growth cell model Solid Paul Ehrlich malignant neoplastic disease comparison traditional tissue and tumor tissue, beneath treatment with the anti-tumor drug immune suppressant drug and cabbage extracted sulforaphane alone and together with methotrexate.

\section{Materials and Methods}

\subsection{Extraction of Sulforaphane}

According to the tactic of Bertelli et al. and Dandan Han et al. [20] [21] with some modifications herbaceous plant, binary compound extracts were ready. Briefly, stuff was ground to a fine homogenized powder then 0.5 gram of pulverized material was left to autolyze in $7 \mathrm{ml} 1 \mathrm{~m} \mathrm{NHCl}$ hydrogen ion concentration three. At $37^{\circ} \mathrm{C}$ night long to permit complete chemical reaction of the sulfur glycosides. The supernatant was filtrated through a bit of gauze then extracted with $5 \mathrm{ml}$ chloride thrice then the dichloromethane fraction was preserved with sodium sulfate anhydrous and dehydrated employing a rotary evaporator at $30^{\circ} \mathrm{C}$. The residue was dissolved in two $\mathrm{ml}$ of twentieth $\mathrm{v} / \mathrm{v}$ acetonitrile and was filtered and injected to solid-phase extraction silicon dioxide column " $10 \mathrm{~cm} \times$ $2.5 \mathrm{~cm}$ silica" that was antecedently equilibrated with chloride. The solid-phase extraction silicon dioxide column then washed with ester as a laundry solvent that may not take away sulforaphane however the opposite inessential compounds, then chloride was used because the extraction solvent in ulterior steps wherever the most important relative quantity of sulforaphane was washed out. The concentration of sulforaphane was resolutely employing a UV1102 photometer. The most wavelength $(\lambda \max )$ that is exclusive for sulforaphane is $240 \mathrm{~nm}$ 
and its molar attenuation constant $\varepsilon$ which is $950 \mathrm{M}^{-1} \cdot \mathrm{cm}^{-1}$ [22]. Sulforaphane was detected by GC-MS victimization Perkin Elmer Clarus 580 Gas chromatograph per the tactic represented by Matusheski et al. [23].

\subsection{Animals}

In this study, sixty feminine anomaly mice advisement concerning 20 - $25 \mathrm{~g}$ were housed and fed customary rat chow and allowed free access to water. They were unbroken beneath constant environmental conditions [temperature $\left(23^{\circ} \mathrm{C} \pm\right.$ $\left.2^{\circ} \mathrm{C}\right)$, ratio $(80 \% \pm 5 \%)$ and light-weight $(12 \mathrm{~h}$ light/dark cycles)]. consistent with the rules of the moral committee of the School of Science, Tanta University all experiments were doled out.

\subsection{Solid Paul Ehrlich Malignant Neoplastic Disease (SEC) Growth Model}

A model of SEC was used, wherever $1 \times 106$ of the Paul Ehrlich malignant neoplastic disease cells (ECC) obtained from the medicine and Experimental Medicine Unit of the NCI, Cairo University, Egypt was constituted subcutaneously into the correct thigh of the limb of mice. A palpable solid growth mass (about $100 \mathrm{~mm}^{3}$ ) was developed among twelve days. By recording the mortality daily for four weeks Mountain Time (Median survival time) was monitored and adaptability ILS (increase in period percent) was calculated [24].

\section{Experimental design:}

Mice were every which way divided into the subsequent teams equally:

- Group I (Negative management group):

The remaining mice were subjected to bacteriologist growth cells that were constituted subcutaneously into the proper thigh of the limb of mice and divided as follow:

- Group II: Tumor-bearing group "Positive management group”.

- Group III: immunosuppressive drug "MTX" was intraperitoneally injected once every three days of a dose of one. $25 \mathrm{mg} / \mathrm{Kg}$ for one month.

- Group IV: $1.5 \mathrm{mg}$ of SFN dissolved in $0.5 \mathrm{ml}$ saline " $50 \mathrm{mg} / \mathrm{Kg}$ ", delivered by internal organ tube once daily in some unspecified time in the future before bacteriologist cells implantation and continued for one month.

- Group V: $1.5 \mathrm{mg}$ of SFN dissolved in saline, delivered by internal organ tube once daily in some unspecified time in the future once bacteriologist cells implantation and continued for one month.

- Group VI (Methotrexate and sulforaphane-treated group): $1.5 \mathrm{mg}$ of SFN dissolved in $0.5 \mathrm{ml}$ saline, delivered by internal organ tube once daily with intraperitoneal MTX once each three days of a dose $1.25 \mathrm{mg} / \mathrm{Kg}$ got in some unspecified time in the future once body covering implantation of bacteriologist cells and continued for one month.

\subsection{Blood Sampling}

The animals were sacrificed at the top of the experiment beneath physiological 
state by decapitation and blood samples were taken and allowed to clot at temperature for half-hour into a dry sterile centrifuge tube, then centrifuged for ten minutes at 5000 r.p.m. Sera were separated and hold on in aliquots at $-80^{\circ} \mathrm{C}$ until be used. Samples were thawed at the temperature at the time of assay activity.

\subsection{Tissue Sampling}

After scarification, Tumors were compound fastidiously, weighed, dimensions measured and washed with cold saline 3 times to get rid of extraneous materials, the neoplasm was chilled on ice and divided into four items that were wrapped in tin foil and hold on at $-80^{\circ} \mathrm{C}$ until used for preparation of tissue homogenates and nuclear extracts [25].

Muscles from the proper thigh of the conventional cluster were compound and washed 3 times with cold saline; the tissue was chilled on ice and divided into four items that were wrapped in tin foil and hold on at $-80^{\circ} \mathrm{C}$ until used for the preparation of tissue homogenates and nuclear extracts [25].

Measurement of neoplasm weight and volume: when animal sacrificing tumors were excised and weighted on grams and volume of the developed tumor mass was calculated [26].

Preparation of neoplasm nuclear macromolecule Extracts: for estimation of total protein content and HDAC activity by employing a membrane, nuclear and protoplasm macromolecule extraction kit equipped by Biobasic INC. Canada [27].

\subsection{Biochemical Assays}

Estimation of macromolecule content within the nuclear extract of neoplasm tissue per the strategy of Lowry et al. (1951) [28]; Histone deacetylase activity was resolute exploitation the colorimetrical HDAC activity assay kit equipped by BioVision USA, Inc.; assessment of polymer harm exploitation the diphenylamine method [29]; determination of lipide Peroxide "Malondialdehyde (MDA)" using lipide peroxide colorimetrical assay kit equipped by Bio Diagnostic Egypt and determination of total inhibitor capability using total antioxidant capacity (TAC) colorimetric assay kit supplied by Bio Diagnostic Egypt.

\subsection{Histological Investigations}

Mice from every cluster were anesthetized with anesthetic ether. Paul Ehrlich solid neoplasm was excised, sliced and washed in saline. Items of Paul Ehrlich neoplasm were mounted in the tenth neutral solution for microscopic anatomy studies. The items of the neoplasm were processed and embedded in paraffin. Sections (5 metric linear units thick) were taken and stained with hematoxylin and fluoresceine for investigation underneath a light-weight magnifier and photographed [30].

\subsection{Statistical Analysis}

To assess the significant unidirectional analysis of variance (ANOVA) was employed in variations among teams and to match all groups with one another. 


\section{Results and Discussion}

In the present work, the naturally chemical irritant sulforaphane was extracted from outer leaves of inexperienced cabbage (B.oleracea) determined mistreatment ultraviolet spectrophotometry in each chloride extract in a very concentration of $661 \mu \mathrm{g} \cdot \mathrm{gm}^{-1}$ recent weight and also the final Acetonitrile extract in a final concentration of $416 \mu \mathrm{g} \cdot \mathrm{gm}^{-1}$ fresh weight. The Acetonitrile extracted SFN was then refined mistreatment silicon dioxide column to an amount of $333 \mu \mathrm{g} \cdot \mathrm{gm}^{-1}$ (Table 1). Sulforaphane was detected by Gas activity (Figure 1). Farag and Motaal extracted SFN from cabbage [31]. Tanongkankit et al. used the microwave-assisted extraction (MAE) to extract sulforaphane from cabbages [24]. Bertelli et al. extracted SNF from the florets, stalks, and leaves of broccoli [20]. The variations in sulforaphane content are related to the variability of plants and its variety and multiple environmental factors, e.g. daily temperatures, soil fertility, microorganism challenge, wounding and plant growth regulators [32] [33].

Ehrlich malignant neoplastic disease is most sensitive to therapy as human tumors that thanks to their undifferentiation and contains an ascension rate. This tumor may be cultivated simply and be a model in vivo (Lisičić et al., 2014). Within the present study, tumor weight and volume were depicted in Tables a pair of. All mice treated with MTX or SFN or each showed a non-significant decrease in tumor weight and volume examination management mice. All mice treated with SFN before carcinogenesis and mice treated with a mixture between intra serosa MTX with oral supplementation of SFN showed a non-significant decrease in tumor weight and volume examination mice within the MTX cluster. Except mice treated with oral SFN once carcinogenesis showed a non-significant increase in tumour weight Conaway et al. conjointly incontestable that the expansion of respiratory organ carcinomas from benign tumors is inhibited by phenethyl chemical irritant and SFN and their N-acetyl amino acid conjugates by reducing cell proliferation and causing cell death within the tobacco carcinogen-treated $\mathrm{A} / \mathrm{J}$ mice supporting the chemopreventive and may be therapeutic potential of those agents in the treatment of human carcinoma (Conaway et al., 2005) and showed the many impacts of treatment the Tuckey check was used.

In this work, there was a major increase in polymer injury in growth tissue scrutiny traditional tissue; also, in polymer injury in growth tissue of mice treated solely with methotrexate sodium, there was a major decrease. Also, a rise in polymer injury together treated cluster scrutiny treatment with methotrexate sodium alone (Table 2). Ferreira First State Oliveira et al. (2014) additionally reportable that the MG-63 osteogenic sarcoma cell line was exposed to SFN at a dietary concentration $(5 \mu \mathrm{M})$ caused in genomic instability by the associate enlarged range of polymer breaks [34] [35].

HDACs were found to be overexpressed in various kinds of cancer [34]. Within the current study, all mice bearing Ehrlich growths showed a major increase in HDAC activity in tumor tissue, scrutiny of traditional mice muscle tis- 
sue. a major decrease in HDAC activity was discovered once treatment with sulforaphane alone or together with the antineoplastic drug methotrexate sodium (Figure 2). In agreement with this knowledge Ho et al. incontestible that sulforaphane inhibits HDAC activity in the human large intestine and glandular carcinoma cells by enhancing simple protein acylation, derepression of P21 and $\mathrm{Bax}$, and induction of cell cycle arrest/apoptosis that result in cancer interference [35] [36].

In this work, there was a major increase in polymer injury in growth tissue scrutiny traditional tissue; additionally, there was a major decrease in polymer injury in growth tissue of mice treated solely with methotrexate sodium. Also, a rise in polymer injury together treated cluster scrutiny treatment with methotrexate sodium alone (Table 2). Ferreira First State Oliveira et al. (2014) additionally reportable that the MG-63 osteogenic sarcoma cell line that exposed to SFN at an amount $(5 \mu \mathrm{M})$ caused genomic instability by the enlarged range of polymer damage [37] [38]. A decrease within the pool of cellular-SH teams are because of the exposure of cells to ITCs like SFN, ITCs chop-chop accumulation in cells as a result of conjugation with living thing thiols, particularly GSH, to levels reaching 100 - to 200 -fold over the animate thing concentrations [39]. That may render cells is also a lot of at-risk of aerophilic stress [40].

The principal and most studied products of unsaturated carboxylic acid peroxidation are Malondialdehyde (MDA). MDA could be an extremely deadly molecule and may be thought of as quite simply a marker of lipoid peroxidation. The interaction of MDA with deoxyribonucleic acid and proteins has typically been noted as doubtless agent and atherogenic [41]. Within the gift work, the MDA level multiplied considerably all told growth tissue and non-significantly increased in tumor tissue treated with each immune suppressant drug and sulforaphane (Table 3). Likewise, First State Oliveira et al. ascertained a rise in intracellular ROS when SFN exposure, and there's a pointy increase was ascertained significantly for the 48-h exposure amount. Moreover, longer exposure times resulted during a larger accumulation of intracellular ROS [37] [38]. The lower SFN concentrations increase the intracellular GSH pool in several cell lines have shown by many studies [42] [43] [44]. Further reports that reckoning on cell line have unconcealed, higher SFN concentrations speedily and markedly drop the intracellular GSH levels [45] [46].

During this study total inhibitor capability (TAC) cut considerably all told growth tissue during a correlational statistics with MDA levels which can be explained with the ensuing result of the SFN conjugation with the intracellular thiols of the tumor cells, like GSH, leading to a decrease within the pool of cellular-SH teams, which is able to doubtless render cells additional at risk of aerophilous stress [47], Is in agreement with Sarban et al. World Health Organization studied the inhibitor arms in patients with atrophic arthritis, they reported associate degree multiplied MDA concentration that is that the most potent marker of aerophilous stress and cut levels of TAC and inhibitor enzymes [48] 
[49].

In our study bodily fluid, TAC has considerably multiplied all told animals except animals with immune suppressant drug treatment alone or together with sulforaphane treatment. Mahmoud et al. evaluated the aerophilous standing and inhibitor defense and its involvement within the relapse of acute lymphocytic leukemia in patients with (ALL), they reported a rise in enzyme, SOD activities, and GSH plasma levels all told patients, as compared with sex-matched controls and a decrease in peroxidase activity [50]; Chou et al. the rotenone-induced reactive gas species production, malondialdehyde (MDA) accumulation are suppressed by sulforaphane treatment, associate degreed resulted in a multiplied level of total glutathione and reduced glutathione (GSH) [20], conjointly Daggulli et al. reported that MDA, Total oxidizer standing, and aerophilous stress index levels were considerably bigger in rats receiving MTX alone relative to the management treated animals whereas the full inhibitor standing level was significantly reduced within the MTX cluster in comparison with the control group [51].

In the current study, there was non-vital decrease in neoplasm weight or volume; however the histopathological examination (Figure 3) showed the accrued p.c of gangrene within the neoplasm tissue treated with SFN and look of variety of apoptotic bodies with tumor regression. Conaway et al. were incontestable that sulforaphane and its $\mathrm{N}$-acetylcysteine conjugates inhibit the expansion of respiratory organ carcinomas from benign tumors by reducing cell proliferation and causing cell death supporting the chemopreventive and may be the therapeutic potential of those agents within the treatment of human carcinoma [51].

The present work recorded a positive vital correlation between HDAC activity and fragmented deoxyribonucleic acid proportion. This can be in agreement with the information according to by Tai et al. that category I HDACs; HDAC2 expression was dramatically correlative with the expression of a group of deoxyribonucleic acid harm repair (DDR) genes, together with RAD51, in carcinoma.

The present work recorded a negative vital correlation between HDAC activity and neoplasm TAC which might be explained by the decreased expression of enzymes chargeable for the inhibitor result like enzyme and SOD as a result of the rise within the HDAC activity. The regulation of animate thing enzyme (EC-SOD) in pneumonic respiratory organ fibroblasts derived from young (up to three months) and previous (24 months) C57BL6 mice are investigated by Roman et al. [50] They according to that repression of EC-SOD expression was related to deacetylation of essential amino acid nine on simple protein $\mathrm{H} 3$ and lysines five, 8 , twelve and sixteen on simple protein $\mathrm{H} 4$ set at the cistron promoter, also, exposure of previous respiratory organ fibroblasts to HDAC class one and sophistication a pair of inhibitors repaired EC-SOD expression to the extent determined in young fibroblasts.

The present study recorded a positive vital correlation between HDAC activity and neoplasm MDA level. Systematically Portakal et al. [51] have found that MDA content in cancerous tissues of the breast was beyond within the corresponding noncancerous tissues. 
Table 1. Tumor DNA damage percent and tumor size.

\begin{tabular}{|c|c|c|c|c|}
\hline Group (n) & & DNA Damage \% & Tumor weight "g" & Tumor volume " $\mathrm{mm}^{3 "}$ \\
\hline \multirow{2}{*}{$\mathrm{I}(10)$} & Range & $5.64-10.21$ & & \\
\hline & Mean \pm S.E. & $7.61 \pm 0.44$ & & \\
\hline \multirow{3}{*}{ II (9) } & Range & $11.57-30.66$ & $0.08-2.5$ & $196.00-18,694.00$ \\
\hline & Mean \pm S.E. & $19.36 \pm 2.03$ & $1.21 \pm 0.26$ & $8303.44 \pm 2080.25$ \\
\hline & $\mathrm{P}^{1}$ & $<0.01$ & & \\
\hline \multirow{4}{*}{$\begin{array}{c}\text { III (7) } \\
\text { MST (23) } \\
\text { ILS (-8\%) }\end{array}$} & Range & $13.10-15.13$ & $0.35-1.8$ & $3140.00-11,902.00$ \\
\hline & Mean \pm S.E. & $14.19 \pm 0.29$ & $1.11 \pm 0.20$ & $7821.85 \pm 1345.28$ \\
\hline & $\mathrm{P}^{1}$ & $<0.01$ & & \\
\hline & $\mathrm{P}^{2}$ & $<0.05$ & N.S. & N.S. \\
\hline \multirow{5}{*}{$\begin{array}{c}\text { IV (9) } \\
\text { MST (28) } \\
\text { ILS (12\%) }\end{array}$} & Range & $17.13-26.07$ & $0.42-1.72$ & $1727.00-10,048.00$ \\
\hline & Mean \pm S.E. & $20.94 \pm 1.10$ & $0.90 \pm 0.16$ & $5119.22 \pm 1233.06$ \\
\hline & $\mathrm{P}^{1}$ & $<0.01$ & & \\
\hline & $\mathrm{P}^{2}$ & N.S. & N.S. & N.S. \\
\hline & $\mathrm{P}^{3}$ & $<0.01$ & N.S. & N.S. \\
\hline \multirow{5}{*}{$\begin{array}{c}\text { V (8) } \\
\text { MST (27.5) } \\
\text { ILS (10\%) }\end{array}$} & Range & $16.91-22.69$ & $0.24-2.50$ & $678.00-17,584.00$ \\
\hline & Mean \pm S.E. & $19.70 \pm 0.81$ & $1.20 \pm 0.30$ & $7621.62 \pm 2437.17$ \\
\hline & $\mathrm{P}^{1}$ & $<0.01$ & & \\
\hline & $\mathrm{P}^{2}$ & N.S. & N.S. & N.S. \\
\hline & $\mathrm{P}^{3}$ & $<0.05$ & N.S. & N.S. \\
\hline \multirow{5}{*}{$\begin{array}{c}\text { VI (8) } \\
\text { MST (27) } \\
\text { ILS (8\%) }\end{array}$} & Range & $18.28-29.01$ & $0.13-1.81$ & $904.00-124,69.00$ \\
\hline & Mean \pm S.E. & $21.63 \pm 1.18$ & $0.98 \pm 0.21$ & $7125.12 \pm 1388.33$ \\
\hline & $\mathrm{P}^{1}$ & $<0.01$ & & \\
\hline & $\mathrm{P}^{2}$ & N.S. & N.S. & N.S. \\
\hline & $\mathrm{P}^{3}$ & $<0.01$ & N.S. & N.S. \\
\hline
\end{tabular}

$\mathrm{P}^{1}$ vs. group I, $\mathrm{P}^{2}$ vs. group II, $\mathrm{P}^{3}$ vs. group III.

Table 2. MDA levels of normal and tumor tissues in comparison with TAC of an animal tumor and normal tissues and serum.

\begin{tabular}{|c|c|c|c|c|}
\hline Group (n) & & MDA in tissue " $\mathrm{nmol} / \mathrm{g}$ " & TAC in tissue "mM/g" & TAC in serum "mM/L" \\
\hline \multirow{2}{*}{ I (10) } & Range & $90.46-164.82$ & $3.5-20.54$ & $10.43-12.69$ \\
\hline & Mean \pm S.E. & $139.21 \pm 8.58$ & $8.23 \pm 1.56$ & $11.63 \pm 0.24$ \\
\hline \multirow{3}{*}{ II (9) } & Range & $223.43-320.60$ & $3.18-4.16$ & $22.25-24.16$ \\
\hline & Mean \pm S.E. & $267.23 \pm 11.37$ & $3.74 \pm 0.10$ & $23.03 \pm 0.21$ \\
\hline & $\mathrm{P}^{1}$ & $<0.05$ & $<0.01$ & $<0.01$ \\
\hline \multirow{4}{*}{ III (7) } & Range & $665.8-1334.24$ & $1.37-1.69$ & $1.27-2.08$ \\
\hline & Mean \pm S.E. & $1009.7 \pm 87.98$ & $1.51 \pm 0.04$ & $1.65 \pm 0.11$ \\
\hline & $\mathrm{P}^{1}$ & $<0.01$ & $<0.01$ & $<0.01$ \\
\hline & $\mathrm{P}^{2}$ & $<0.01$ & N.S. & $<0.01$ \\
\hline
\end{tabular}




\begin{tabular}{ccccc} 
Continued & \multicolumn{5}{c}{} \\
\hline & Range & $459.82-663.87$ & $1.83-2.5$ & $17.52-20.10$ \\
IV (9) & Mean \pm S.E. & $555.21 \pm 21.28$ & $2.18 \pm 0.085$ & $19.13 \pm 0.32$ \\
& $\mathrm{P}^{1}$ & $<0.01$ & $<0.01$ & $<0.01$ \\
& $\mathrm{P}^{2}$ & $<0.01$ & N.S. & $<0.01$ \\
& $\mathrm{P}^{3}$ & $<0.01$ & N.S. & $<0.01$ \\
& Range & $353.21-452.28$ & $2.59-2.97$ & $20.22-22.01$ \\
& Mean \pm S.E. & $418.92 \pm 12.75$ & $2.81 \pm 0.051$ & $21.13 \pm 0.24$ \\
& $\mathrm{P}^{1}$ & $<0.01$ & $<0.01$ & $<0.01$ \\
& $\mathrm{P}^{2}$ & $<0.05$ & N.S. & $<0.01$ \\
& $\mathrm{P}^{3}$ & $<0.01$ & N.S. & $<0.01$ \\
& Range & $165.26-223.57$ & $4.25-5.73$ & $6.89-8.61$ \\
& Mean \pm S.E. & $191.34 \pm 6.7$ & $4.68 \pm 0.19$ & $7.67 \pm 0.213$ \\
VI (8) & $\mathrm{P}^{1}$ & N.S. & $<0.05$ & $<0.01$ \\
& $\mathrm{P}^{2}$ & N.S. & N.S. & $<0.01$ \\
$\mathrm{P}^{3}$ & $<0.01$ & N.S. & $<0.01$ \\
\hline
\end{tabular}

$\mathrm{P}^{1}$ vs. group I, $\mathrm{P}^{2}$ vs. group II, $\mathrm{P}^{3}$ vs. group III.

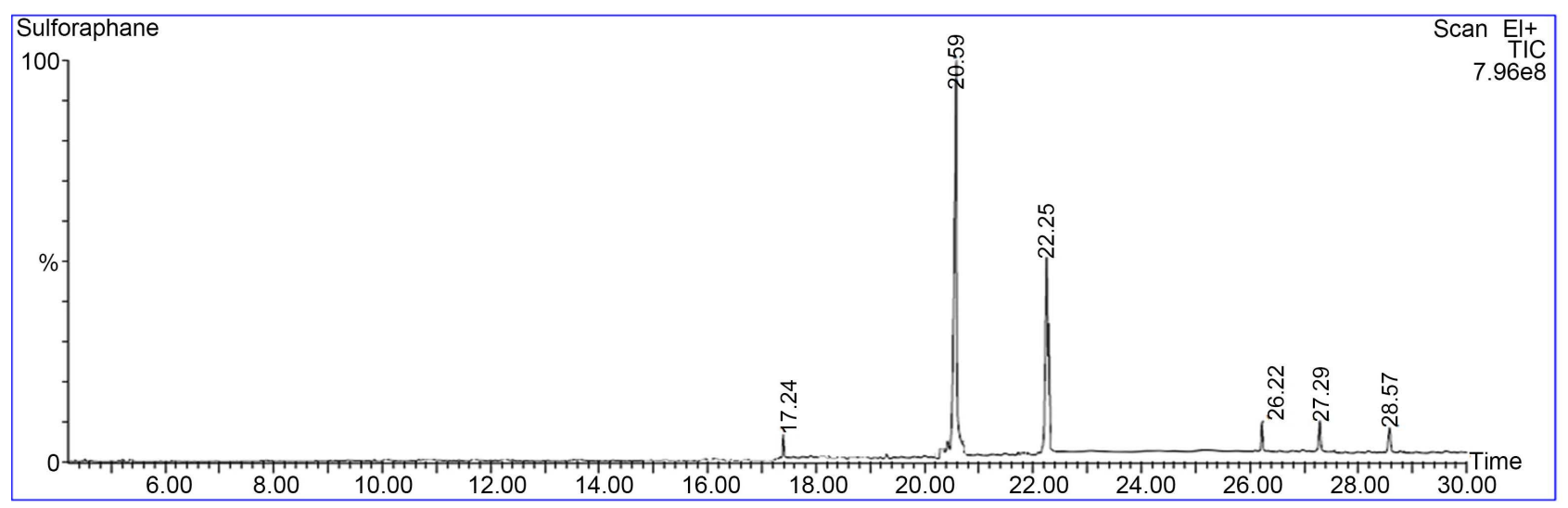

Figure 1. GC spectrum of sulforaphane which appears with a significant peak at retention time of 20.59.

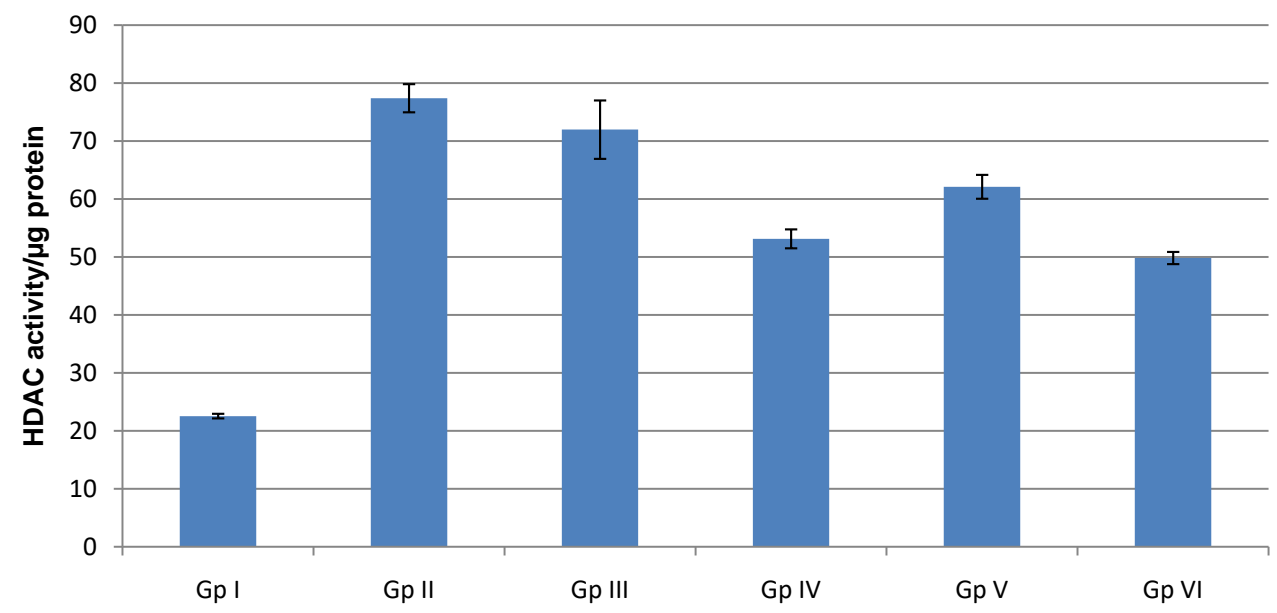

Figure 2. Tumor HDAC activity in different mice groups. 

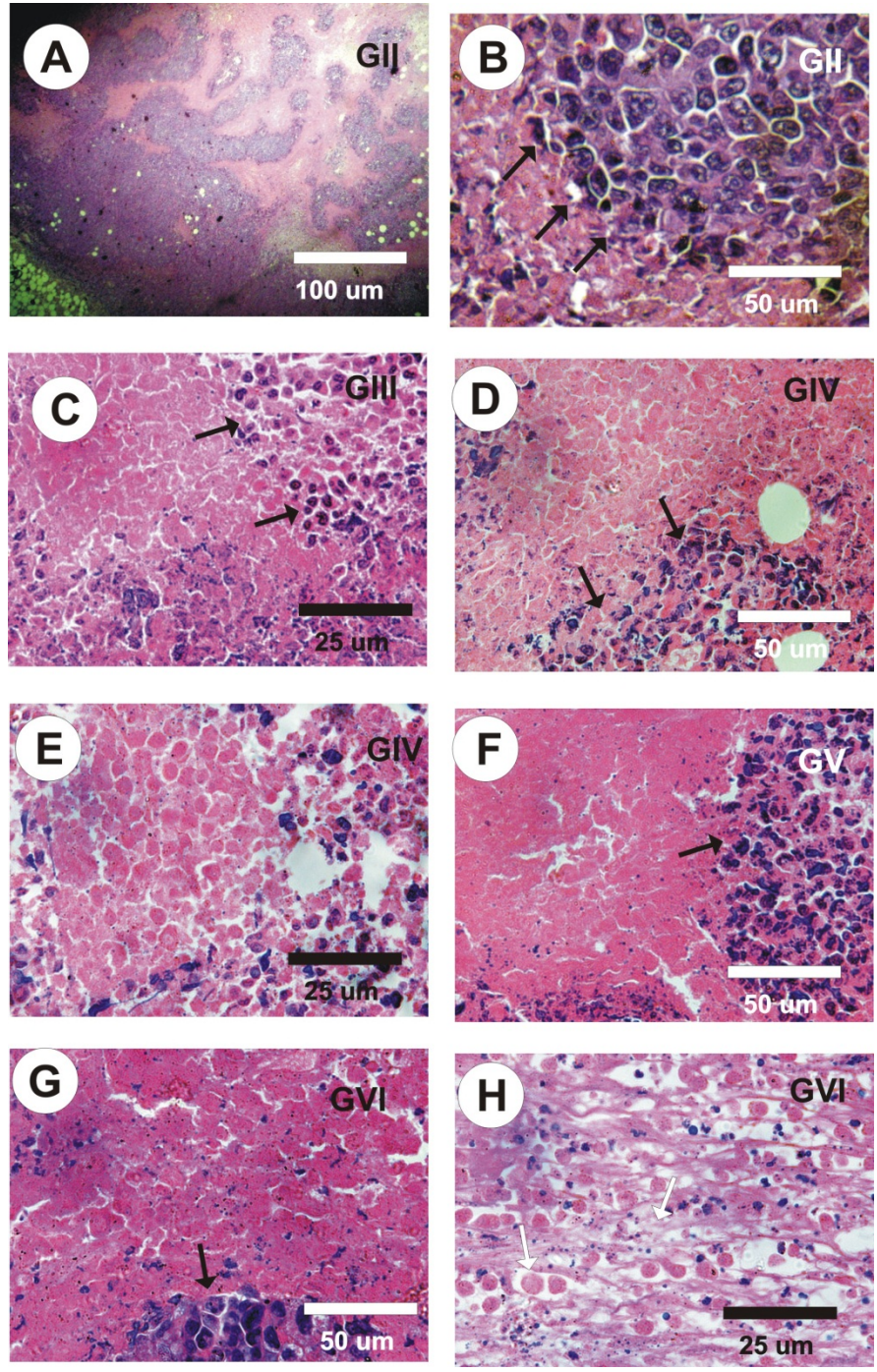

Figure 3. (A-H): Photomicrograph of tumor sections in the different experimental groups stained with Haematoxylin \& Eosin. A \& B: Tumor sections in SEC (GII) revealed compact and aggregation of the tumor tissue cells (Black arrows) spread within the muscular tissues. C: Tumor sections in SEC treated with MTX revealed a high regression of tumor development and spread within the muscle tissue. D \& E: Tumor sections in SEC pre-treated with SFN revealed a good improvement and presence of many apoptotic bodies and an increase in necroses area. F: Tumor sections in SEC post-treated with SFN revealed moderate numbers of apoptotic bodies with a tumor regression. G \& H: Tumor sections in SEC treated with MTX and SFN revealed a very good improvement, most of the tumor areas were recovered (Black arrows), high and wide zones of apoptotic cells and other many zones of tumor cells remnants.

Table 3. Correlations.

\begin{tabular}{|c|c|c|c|c|c|c|c|}
\hline & & $\begin{array}{c}\text { Fragmented } \\
\text { DNA\% }\end{array}$ & Serum TAC & Tumor TAC & Tumor MDA & $\begin{array}{l}\text { Tumor } \\
\text { Weight }\end{array}$ & $\begin{array}{l}\text { Tumor } \\
\text { Volume }\end{array}$ \\
\hline \multirow{2}{*}{$\begin{array}{l}\text { HDAC } \\
\text { activity }\end{array}$} & $\mathrm{r}$ & $0.481^{\star *}$ & 0.230 & $-0.565^{\star *}$ & $0.496^{* *}$ & $0.510^{\star *}$ & $0.467^{* *}$ \\
\hline & $\mathrm{P}$ & $<0.001$ & 0.104 & $<0.001$ & $<0.001$ & $<0.001$ & 0.001 \\
\hline
\end{tabular}




\section{Conclusion}

SFN could be a natural ITC that found in cabbage outer leaves at a degree of 83.3 $\mu \mathrm{g} / \mathrm{gm}^{-1}$ recent weight. It showed a repressive result to HDAC in Paul Ehrlich solid tumor tissue once given orally. SFN conjointly showed a pro-oxidant activity in tumor tissue compared with MTX treatment. These results recommend that SFN could also be probably used as AN anticancer agent.

\section{Acknowledgements}

Thanks to Dr. Marwa Mahound Atef Khalid for supply chemicals employed in DNA broken assay.

\section{Conflicts of Interest}

The authors declare no conflicts of interest regarding the publication of this paper.

\section{References}

[1] Bao, J. and Qiao, L. (2017) New Developments in Targeted Cancer Therapy. Cancer Letters, 387, 1-2. https://doi.org/10.1016/j.canlet.2016.12.016

[2] Ceylan, D., et al. (2017) The Effects of Gilaburu (Viburnum opulus) Juice on Experimentally Induced Ehrlich Ascites Tumor in Mice.

[3] Choudhury, G. and MacNee, W. (2017) Role of Inflammation and Oxidative Stress in the Pathology of Ageing in COPD: Potential Therapeutic Interventions. COPD. Journal of Chronic Obstructive Pulmonary Disease, 14, 122-135. https://doi.org/10.1080/15412555.2016.1214948

[4] Nunomura, A. (2016) Idiopathic Basal Ganglia Calcification (Fahr's Disease) and Dementia. Psychiatry and Clinical Neurosciences, 70, 129-130. https://doi.org/10.1111/pcn.12378

[5] Margaritelis, N.V., Cobley, J.N., Paschalis, V., Veskoukis, A.S., Theodorou, A.A., et al. (2016) Going Retro: Oxidative Stress Biomarkers in Modern Redox Biology. Free Radical Biology \& Medicine, 98, 2-12. https://doi.org/10.1016/j.freeradbiomed.2016.02.005

[6] Tharmalingam, S., Sreetharan, S., Kulesza, A.V., Boreham, D.R. and Tai, T.C. (2017) Low-Dose Ionizing Radiation Exposure, Oxidative Stress and Epigenetic Programming of Health and Disease. Radiation Research, 188, 525-538. https://doi.org/10.1667/RR14587.1

[7] Hsieh, C.-L., et al. (2016) Alterations in Histone Deacetylase 8 Lead to Cell Migration and Poor Prognosis in Breast Cancer. Life Sciences, 151, 7-14. https://doi.org/10.1016/j.lfs.2016.02.092

[8] Serrano-Gomez, S.J., Maziveyi, M. and Alahari, S.K. (2016) Regulation of Epithelial-Mesenchymal Transition through Epigenetic and Post-Translational Modifications. Molecular Cancer, 15, Article No. 18. https://doi.org/10.1186/s12943-016-0502-X

[9] Wright, L.H. and Menick, D.R. (2016) A Class of Their Own: Exploring the Non-Deacetylase Roles of Class IIa HDACs in Cardiovascular Disease. American Journal of Physiology-Heart and Circulatory Physiology, 2016, ajpheart.00271. https://doi.org/10.1152/ajpheart.00271.2016 
[10] Harada, T., Hideshima, T. and Anderson, K.C. (2016) Histone Deacetylase Inhibitors in Multiple Myeloma: From Bench to Bedside. International Journal of Hematology, 104, 300-309. https://doi.org/10.1007/s12185-016-2008-0

[11] Lee, C.-H., et al. (2017) Efficacy and Safety of Micafungin versus Extensive Azoles in the Prevention and Treatment of Invasive Fungal Infections for Neutropenic Patients with Hematological Malignancies: A Meta-Analysis of Randomized Controlled Trials. PLoS ONE, 12, e0180050.

https://doi.org/10.1371/journal.pone.0180050

[12] Shao, G., et al. (2017) Inactivation of EGFR/AKT Signaling Enhances TSA-Induced Ovarian Cancer Cell Differentiation. Oncology Reports, 37, 2891-2896. https://doi.org/10.3892/or.2017.5556

[13] Li, R., et al. (2017) Glucoraphanin, Sulforaphane, and Antiproliferative Capacity of Radish Sprouts in Germinating and Thermal Processes. European Food Research and Technology, 243, 547-554. https://doi.org/10.1007/s00217-016-2764-3

[14] Sosa, V., et al. (2013) Oxidative Stress and Cancer: An Overview. Aging Research Reviews, 12, 376-390. https://doi.org/10.1016/j.arr.2012.10.004

[15] Zhang, Y. and Tang, L. (2007) Discovery and Development of Sulforaphane as a Cancer Chemopreventive Phytochemical. Acta pharmacologica Sinica, 28, 1343-1354. https://doi.org/10.1111/j.1745-7254.2007.00679.x

[16] Catanzaro, E. and Fimognari, C. (2017) Antileukemic Activity of Sulforaphane, in Glucosinolates. Springer, Berlin, 301-317.

https://doi.org/10.1007/978-3-319-25462-3_14

[17] Bertelli, D., et al. (1998) Separation by Solid Phase Extraction and Quantification by Reverse Phase HPLC of Sulforaphane in Broccoli. Food Chemistry, 63, 417-421. https://doi.org/10.1016/S0308-8146(98)00052-1

[18] Han, D. and Row, K.H. (2011) Separation and Purification of Sulforaphane from Broccoli by Solid Phase Extraction. International Journal of Molecular Sciences, 12, 1854-1861. https://doi.org/10.3390/ijms12031854

[19] Tao, S., et al. (2017) p97 Negatively Regulates NRF2 by Extracting Ubiquitylated NRF2 from the KEAP1-CUL3 E3 Complex. Molecular and Cellular Biology, 37, MCB.00660-16.

[20] Matusheski, N.V., et al. (2001) Preparative HPLC Method for the Purification of Sulforaphane and Sulforaphane Nitrile from Brassica oleracea. Journal of Agricultural and Food Chemistry, 49, 1867-1872. https://doi.org/10.1021/jf0013860

[21] Tanongkankit, Y., et al. (2013) Microwave-Assisted Extraction of Sulforaphane from White Cabbages: Effects of Extraction Condition, Solvent and Sample Pretreatment. Journal of Food Engineering, 117, 151-157. https://doi.org/10.1016/j.jfoodeng.2013.02.011

[22] Chastre, J., et al. (1984) Prospective Evaluation of the Protected Specimen Brush for the Diagnosis of Pulmonary Infections in Ventilated Patients 1â-3. American Review of Respiratory Disease, 130, 924-929.

[23] Attia, M.A.M. and Weiss, D.W. (1966) Immunology of Spontaneous Mammary Carcinomas in Mice. Cancer Research, 26, 1787-1800.

[24] Ouyang, W., et al. (2009) Soluble and Insoluble Nickel Compounds Exert a Differential Inhibitory Effect on Cell Growth through IKKalpha®ependent Cyclin D1 Down-Regulation. Journal of Cellular Physiology, 218, 205-214. https://doi.org/10.1002/jcp.21590

[25] Lowry, O.H., et al. (1951) Protein Measurement with the Folin Phenol Reagent. The 
Journal of Biological Chemistry, 193, 265-275.

[26] Zhu, W.-H., Majluf-Cruz, A. and Omburo, G.A. (1998) Cyclic AMP-Specific Phosphodiesterase Inhibitor Rolipram and RO-20-1724 Promoted Apoptosis in HL60 Promyelocytic Leukemia Cells via the Cyclic AMP-Independent Mechanism. Life Sciences, 63, 265-274. https://doi.org/10.1016/S0024-3205(98)00270-7

[27] Hakoda, K., Yoshimitsu, M., Emi, M., et al. (2017) The Complete Pathological Response of Multiple Huge Liver Metastases of Colon Cancer: A Case Report. Oxford Medical Case Reports, 2017, omx016. https://doi.org/10.1093/omcr/omx016

[28] Farag, M.A. and Motaal, A.A.A. (2010) Sulforaphane Composition, a Cytotoxic and Antioxidant Activity of Crucifer Vegetables. Journal of Advanced Research, 1, 65-70. https://doi.org/10.1016/j.jare.2010.02.005

[29] Fernández-León, A.M., et al. (2017) Quantification and Bioaccessibility of Intact Glucosinolates in Broccoli "Parthenon" and Savoy Cabbage "Dama". Journal of Food Composition and Analysis, 61, 40-46. https://doi.org/10.1016/j.jfca.2016.11.010

[30] Francisco, M., et al. (2017) A Nutritional and Phytochemical Value of Brassica Crops from the Agri-Food Perspective. Annals of Applied Biology, 170, 273-285. https://doi.org/10.1111/aab.12318

[31] Spehalski, E.I., Tofilon, P.J. and Camphausen, K. (2017) Histone Deacetylase Inhibitors and Tumor Radiosensitization. In: Increasing the Therapeutic Ratio of Radiotherapy, Springer, Berlin, 57-78. https://doi.org/10.1007/978-3-319-40854-5_3

[32] Ho, E., Clarke, J.D. and Dashwood, R.H. (2009) Dietary Sulforaphane, a Histone Deacetylase Inhibitor for Cancer Prevention. The Journal of Nutrition, 139, 2393-2396. https://doi.org/10.3945/jn.109.113332

[33] Johnson, G.S., et al. (2017) A Functional Pseudogene, NMRAL2P, Is Regulated by Nrf2 and Serves as a Coactivator of NQO1 in Sulforaphane-Treated Colon Cancer Cells. Molecular Nutrition \& Food Research, 61, Article ID: 1600769. https://doi.org/10.1002/mnfr.201770041

[34] Ferreira de Oliveira, J.M.P., et al. (2014) Sulforaphane Induces DNA Damage and Mitotic Abnormalities in Human Osteosarcoma MG-63 Cells: Correlation with Cell Cycle Arrest and Apoptosis. Nutrition and Cancer, 66, 325-334. https://doi.org/10.1080/01635581.2014.864777

[35] Coutinho, L., et al. (2017) Hesperetin-Etoposide Combinations Induce Cytotoxicity in $\mathrm{U}_{2} \mathrm{OS}$ Cells: Implications on Therapeutic Developments for Osteosarcoma. DNA Repair, 50, 36-42. https://doi.org/10.1016/j.dnarep.2016.12.006

[36] Ling, X., Westover, D., Cao, F., et al. (2015) Synergistic Effect of Allyl Isothiocyanate (AITC) on Cisplatin Efficacy in Vitro and in Vivo. American Journal of Cancer Research, 5, 2516-2530.

[37] Hu, R. and Xie, X.Y. (2017) PM2.5 Exposure Elicits Oxidative Stress Responses and Mitochondrial Apoptosis Pathway Activation in HaCaT Keratinocytes. Chinese Medical Journal, 130, 2205-2214. https://doi.org/10.4103/0366-6999.212942

[38] Carrillo, W., Guzmán, X. and Vilcacundo, E. (2017) Native and Heated Hydrolysates of Milk Proteins and Their Capacity to Inhibit Lipid Peroxidation in the Zebrafish Larvae Model. Foods, 6, 81. https://doi.org/10.3390/foods6090081

[39] Tarozzi, A., et al. (2016) Combined Inhibition of the EGFR/AKT Pathways by a Novel Conjugate of Quinazoline with Isothiocyanate. European Journal of Medicinal Chemistry, 117, 283-291. https://doi.org/10.1016/j.ejmech.2016.04.002 
[40] Olagnier, D., et al. (2017) Activation of Nrf2 Signaling Augments Vesicular Stomatitis Virus Oncolysis via Autophagy-Driven Suppression of Antiviral Immunity. Molecular Therapy, 25, 1900-1916. https://doi.org/10.1016/j.ymthe.2017.04.022

[41] Dickinson, S.E., et al. (2015) The Effect of Sulforaphane on Histone Deacetylase Activity in Keratinocytes: Differences between in Vitro and in Vivo Analyses. Molecular Carcinogenesis, 54, 1513-1520. https://doi.org/10.1002/mc.22224

[42] Vyas, A.R., Moura, M.B., Hahm, E.R., Singh, K.B. and Singh, S.V. (2016) Sulforaphane Inhibits c-Myc-Mediated Prostate Cancer Stem-Like Traits. Journal of Cellular Biochemistry, 117, 2482-2495. https://doi.org/10.1002/jcb.25541

[43] Amjad, A.I., et al. (2015) Broccoli-Derived Sulforaphane and Chemoprevention of Prostate Cancer: From Bench to Bedside. Current Pharmacology Reports, 1, 382-390. https://doi.org/10.1007/s40495-015-0034-x

[44] Leone, A., et al. (2017) Sulforaphane for the Chemoprevention of Bladder Cancer: Molecular Mechanism Targeted Approach. Oncotarget, 8, 35412-35424. https://doi.org/10.18632/oncotarget.16015

[45] Sarban, S., Kocyigit, A. and Yazar, M. (2005) Plasma Total Antioxidant Capacity, Lipid Peroxidation, and Erythrocyte Antioxidant Enzyme Activities in Patients with Rheumatoid Arthritis and Osteoarthritis. Clinical Biochemistry, 38, 981-986. https://doi.org/10.1016/j.clinbiochem.2005.08.003

[46] Sönmez, M.M., et al. (2017) Minimal Invasive Fixation of Distal Tibial Fractures Does Not Result in Rotational Malalignment: A Report of 24 Cases with CT Imaging. Ulusal Travma ve Acil Cerrahi Dergisi, 23, 144-149.

[47] Mahmoud, L.B., et al. (2017) Oxidative Stress in Tunisian Patients with Acute Lymphoblastic Leukemia and Its Involvement in Leukemic Relapse. Journal of Pediatric Hematology/Oncology, 39, e124-e130. https://doi.org/10.1097/MPH.0000000000000793

[48] Daggulli, M., et al. (2014) Protective Effects of Carvacrol against Methotrexate-Induced Testicular Toxicity in Rats. International Journal of Clinical and Experimental Medicine, 7, 5511-5516.

[49] Conaway, C.C., et al. (2005) Phenethyl Isothiocyanate and Sulforaphane and Their $\mathrm{N}$-Acetylcysteine Conjugates Inhibit Malignant Progression of Lung Adenomas Induced by Tobacco Carcinogens in A/J Mice. Cancer Research, 65, 8548-8557. https://doi.org/10.1158/0008-5472.CAN-05-0237

[50] Roman, J., Zhu, J., Ritzenthaler, J.D. and Zelko, I.N. (2017) Epigenetic Regulation of EC-SOD Expression in Aging Lung Fibroblasts: Role of Histone Acetylation. Free Radical Biology and Medicine, 112, 212-223. https://doi.org/10.1016/j.freeradbiomed.2017.07.028

[51] Portakal, O., et al. (2000) Coenzyme Q10 Concentrations and Antioxidant Status in Tissues of Breast Cancer Patients. Clinical Biochemistry, 33, 279-284. https://doi.org/10.1016/S0009-9120(00)00067-9 